\title{
Prospects of poultry subcomplex development of Russia in new conditions
}

\author{
A.N. Semin*, D.A. Karkh, I.S. Kondratenko \\ Ural State University of Economics, 620144 Ekaterinburg, Russia
}

\begin{abstract}
Poultry subcomplex is one of the key links of the agroindustrial complex of Russia. Its importance is due to the fact that in times of crisis it is able to provide all segments of the population with inexpensive but protein nutritious and dietary products. Due to new challenges when the country stands on the threshold of crisis phenomena manifestation in the economy, the development of the poultry subcomplex receives a new impulse. However, it is necessary to be based not only on the previous experience of its functioning, but also to take into account the new requirements of the poultry market. This is confirmed by indicators of subcomplex development.
\end{abstract}

\section{Introduction}

The poultry subcomplex (PSC), after rapid growth in the late zero-tenths of the $21 \mathrm{st}$ century, began to surrender its positions. Moreover, 2018 became a crisis year in the industry with the closure of poultry farms and the decline of production at the remaining enterprises. This was not so much because of the decrease in demand, but as a result of the costs share increase for the production of poultry products at low purchase prices.

This situation was created by the overlay of several problems. Thus, the increase in cost was influenced by the fact that some of the components of combined feed produced in Russia are imported; when the ruble is weakened, the costs under the "feed" article increase. The depth of raw materials processing has been increasing in recent years, but this is mainly true of poultry meat, and in the egg direction this is represented to a lesser extent.

In 2018, the situation with overproduction of poultry meat led to the continued decline in purchase prices. According to the Institute of Agrarian Market Conditions, in 20174.9 million tons [6] of chicken meat were produced with domestic consumption of 4.5-4.6 million tons. At the same time, export amounted to only 0.16 million tons [4] due to the difficulty of entering the foreign market. However, in the last two years there have been positive trends in shipments abroad, mainly to the countries of South-East Asia: in 2018 exports amounted to 0.18 million tons, and in $2019-0.20$ thousand tons [8]. The opening of new markets can give a boost to the development of the poultry subcomplex, especially since there are reserves for this.

\footnotetext{
*Corresponding author: aleks_ural_55@mail.ru
} 


\section{Research}

The share of poultry in 2018 accounted for $36.6 \%$ of world meat production (in 1950 half less - only $17.1 \%$ ). Such volumes are comparable only to pork production. In Russia the specific weight of poultry meat was increasing, but in 2018-2019 there was a decrease (Figure 1).

But despite the deterioration in the structure of meat relative to poultry, its level is still high, more than double the 2001-2005 average. For 2006-2010, the share of poultry increased by one and a half times compared to the previous period, when the revival of the domestic poultry industry began, and in 2017 reached a peak of $48.1 \%$. The backdown of poultry positions occurred due to the growth of the specific weight of pork. This follows from the chart in Figure 2.

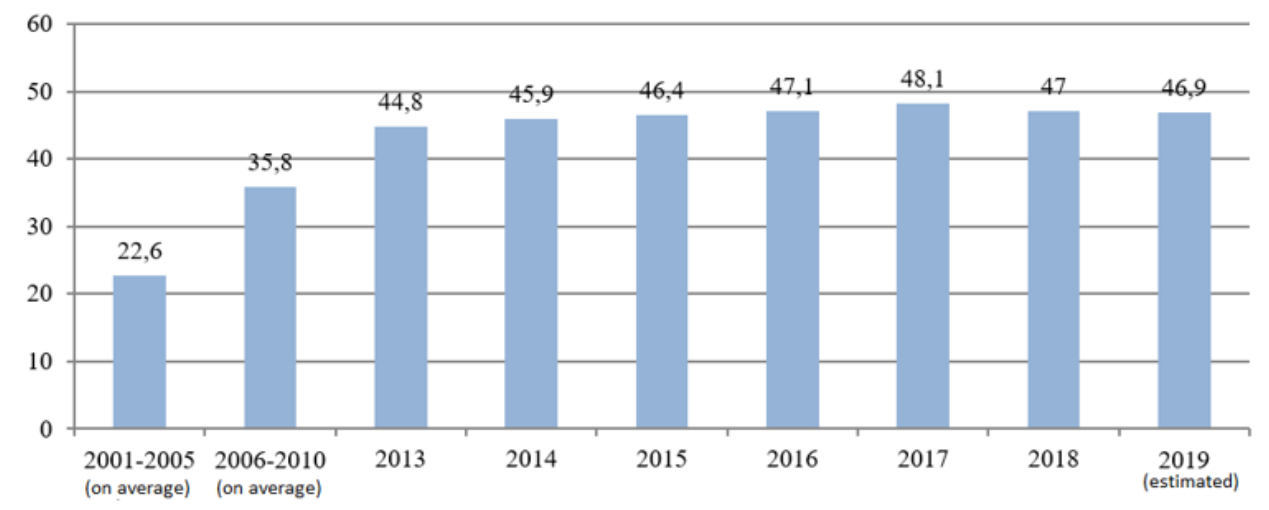

Fig. 1. Share of poultry in the structure of meat production in Russia $[3,11,5], \%$

We refer the poultry subcomplex to the system of agro-industrial complex as an element of the animal husbandry subsystem. A systematic approach to the concepts of agroindustrial complex and poultry subcomplex allows to consider them not as a set of components, but primarily the relationship between constituent parts.

Such a unit is seen as useful because within livestock there is also a link between its elements: thus, the reduction of consumption and hence beef production leads to increased consumption of pork or poultry meat. The decline in poultry meat consumption is associated with switching to pork. The reasons for the situation are most often a change in the real income of the population, a decrease or increase in solvent demand. Imbalances can also be caused by a shortage of poultry meat, although such situations are rare in market economy. This can be illustrated graphically. 


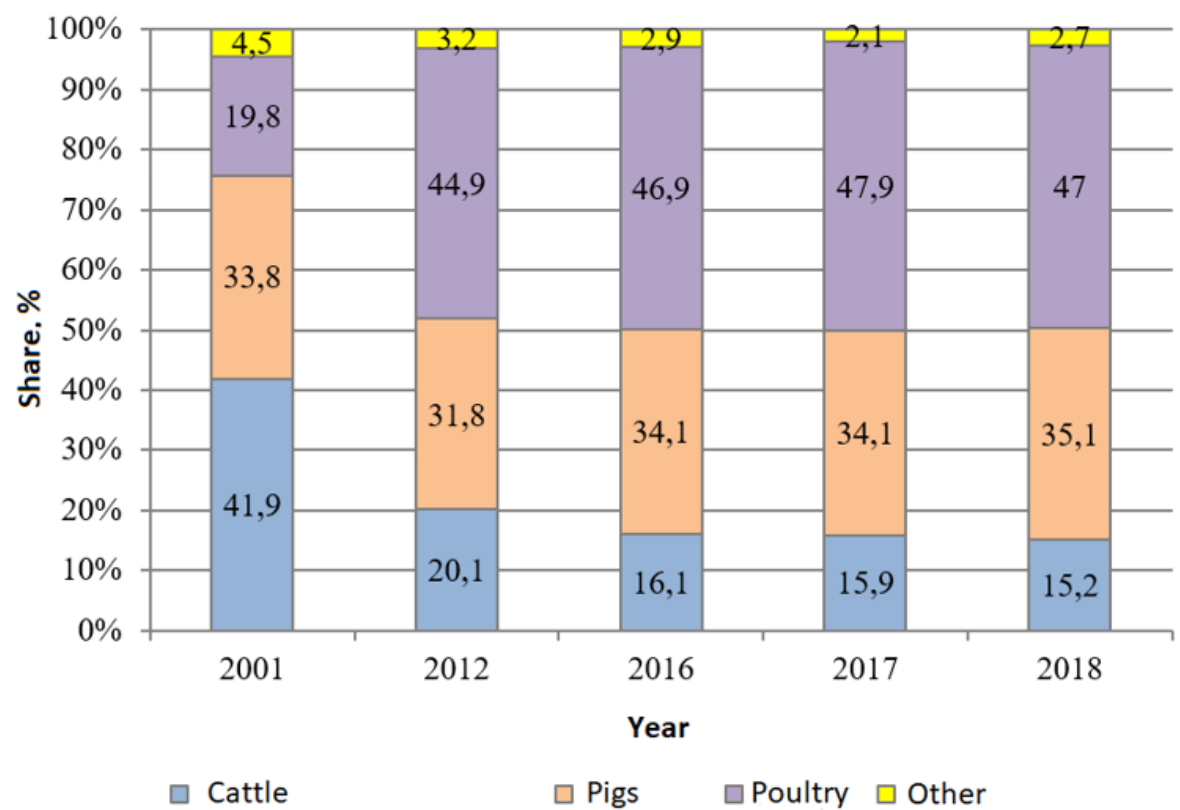

Fig. 2. Structure of basic livestock products production [11]

Figure 2 shows the change in the structure of livestock in Russia in 2001-2018. It is evident that there was a constant reduction in the specific weight of cattle - from $41.9 \%$ in 2001 to $15.2 \%$ in 2018 . This was due to the growth of the poultry share from $19.8 \%$ in 2001 to $47.9 \%$ in 2017 . But in 2018 there was a decrease in the specific weight of poultry in livestock production by $0.9 \%$. This reflects the market saturation with poultry meat and the difficulties encountered in its marketing.

The changes in the poultry share in the structure of meat production, presented in Figure 1 and 2, fit into the overall trend of poultry subcomplex development against the background of existing problems. In the conditions of market saturation, they can be solved simultaneously in three ways: to increase the solvent demand of the population, to increase the share of the use of poultry and eggs in the production of finished processed products, continue to enter foreign markets. And the factors for such growth in the industry, in our opinion, are available. Even if the consumption of eggs per capita is compared, by 1990 it was 322 pieces [9], and in 2018 this figure was 307 pieces [11].

The average annual egg yield of laying hens in agricultural organizations is shown in Figure 3. Given that the production of eggs is handled by the population and farms, domestic consumption can be fully provided by domestic eggs. Figure 3 shows that the productivity of poultry over the last 6 years showed first growth, then reduction. At the same time in 2010 compared to 2000 the average annual egg yield of laying hens in agricultural organizations increased by almost $16.3 \%$, in 2015 compared to 2010 - by $1 \%$. 


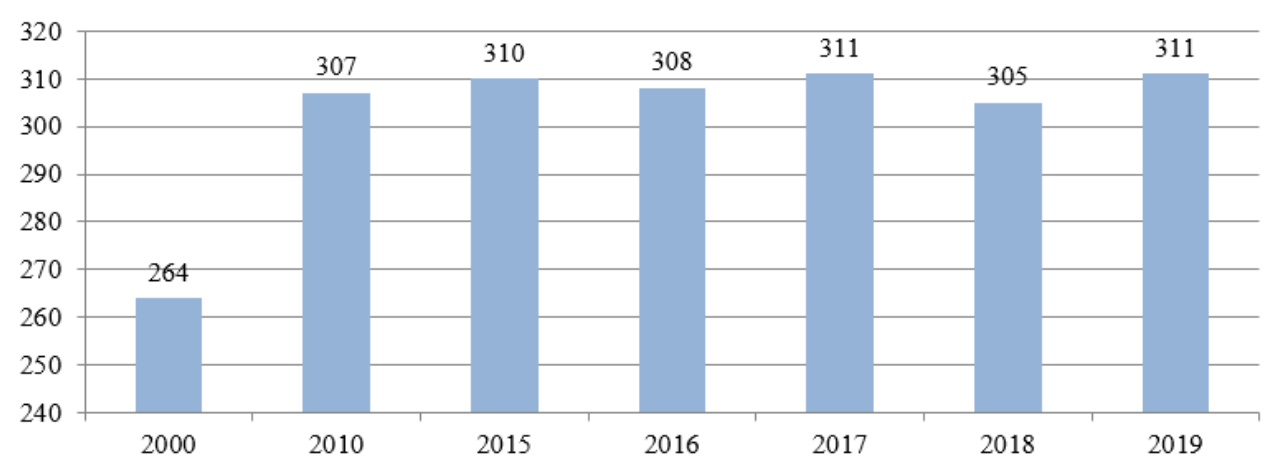

Fig. 3. Average annual egg yield of laying hens in agricultural organizations, pcs [11].

Table 1 shows the dynamics of the main indicators of agricultural organizations activity in the poultry subcomplex of Russia.

Table 1. Dynamics of main activity indicators of agricultural organizations of poultry subcomplex in the XXI century $[11,5]$.

\begin{tabular}{|l|c|c|c|c|c|c|c|c|}
\hline \multicolumn{1}{|c|}{ Indicator } & \multicolumn{7}{c|}{ Years } \\
\cline { 2 - 9 } & 2000 & 2005 & 2010 & 2015 & 2016 & 2017 & 2018 & 2019 \\
\hline $\begin{array}{l}\text { Number of poultry at the } \\
\text { end of the year, million } \\
\text { heads }\end{array}$ & 205 & 241 & 348 & 445 & 452 & 460 & 449 & 454 \\
\hline $\begin{array}{l}\text { Production of poultry for } \\
\text { slaughter (in } \\
\text { carcass weight), million } \\
\text { tons: }\end{array}$ & 0.5 & 1.1 & 2.5 & 4.5 & 4.6 & 4.9 & 5.0 & 5.1 \\
\hline $\begin{array}{l}\text { Egg production, billion } \\
\text { pcs. }\end{array}$ & 24.2 & 27.3 & 31.3 & 31.0 & 31.5 & 33.6 & 33.9 & 33.9 \\
\hline $\begin{array}{l}\text { Dynamics, in \% to } \\
\text { previous period }\end{array}$ & 2000 & 2005 & 2010 & 2015 & 2016 & 2017 & 2018 & 2019 \\
\hline $\begin{array}{l}\text { Year-end bird } \\
\text { population,\% }\end{array}$ & - & 117.6 & 144.4 & 127.9 & 101.6 & 101.8 & 97.6 & 101.1 \\
\hline $\begin{array}{l}\text { Production of poultry for } \\
\text { slaughter (in } \\
\text { carcass weight), \% }\end{array}$ & - & 220.0 & 227.3 & 180.0 & 102.2 & 106.5 & 102.0 & 102.0 \\
\hline Egg production,\% & - & 112.8 & 114.7 & 99.0 & 101.6 & 106.7 & 100.9 & 100.0 \\
\hline
\end{tabular}

Table 1 clearly shows that between 2000 and 2015 the poultry industry developed dynamically. Calculated the average growth rate of poultry for every five years was $129.5 \%$. And if we compare 2019 with 2015, a growth of only $2 \%$ was obtained. A negative contribution was made for the industry in 2018 by the crisis, when the number of poultry decreased by $2.4 \%$.

A similar pattern is observed for the production of poultry for slaughter. Every five years there was a doubling of the value, and in 2019 compared to 2015 the growth was $113.3 \%$, which is much less. On average, egg production has increased by $8.6 \%$ every five years between 2000 and 2015, and by $10 \%$ over the past five years. This is due to the fact that for the egg direction the crisis was not 2018, but 2015, hence this dynamic. At the same time, the growth of egg production in 2019 stopped.

If we compare data for 2019 and 2000, it will be found that the number of poultry increased by 1.9 times over 20 years, and the production of poultry for slaughter by 4.6 times. This is due to the fact that the average mass of one bird was constantly increased by 
the use of special feed additives and breeds with increased mass. But at the same time, the quality of meat deteriorated, became more stringent especially in the thorax part. Egg production only increased 1.2 times. This is due to the fact that in the $1990 \mathrm{~s}$, although their production and consumption decreased, there was no active import intervention in this direction, which cannot be said about poultry meat.

The number of poultry is divided into categories of farms (table 2). It is seen that there is a steady increase in the share of agricultural organizations in the number of poultry. And if in 2010 they accounted for $77.3 \%$, in 2019 it was already $83.3 \%$. This is accompanied by a reduction in the specific weight of the livestock, from 21.5 to $14.9 \%$ for the specified period. Peasant (farm) holdings were $1.1 \%$ in 2010 , and average $1.8 \pm 1 \%$ in $2016-2019$. Thus, the state of the poultry market is more determined by agricultural organizations, the share of farming is extremely low.

Table 2. Number of poultry by category of farms (year-end) [11]

\begin{tabular}{|c|c|c|c|c|c|c|c|c|c|c|}
\hline \multirow[t]{2}{*}{ Indicator } & \multicolumn{2}{|c|}{2010} & \multicolumn{2}{|c|}{2016} & \multicolumn{2}{|c|}{2017} & \multicolumn{2}{|c|}{2018} & \multicolumn{2}{|c|}{2019} \\
\hline & $\begin{array}{c}\text { milli } \\
\text { on } \\
\text { head } \\
\text { s }\end{array}$ & $\begin{array}{c}\text { share, } \\
\%\end{array}$ & $\begin{array}{c}\text { milli } \\
\text { on } \\
\text { head } \\
\text { s }\end{array}$ & $\begin{array}{l}\text { sha } \\
\text { re, } \\
\%\end{array}$ & $\begin{array}{c}\text { milli } \\
\text { on } \\
\text { head } \\
\text { s }\end{array}$ & $\begin{array}{c}\text { share, } \\
\%\end{array}$ & $\begin{array}{c}\text { millio } \\
n \\
\text { heads }\end{array}$ & $\begin{array}{c}\text { share } \\
, \%\end{array}$ & $\begin{array}{c}\text { milli } \\
\text { on } \\
\text { head } \\
\text { s }\end{array}$ & $\begin{array}{l}\text { shar } \\
\text { e, } \%\end{array}$ \\
\hline $\begin{array}{l}\text { The number of } \\
\text { poultry in farms } \\
\text { of all categories }\end{array}$ & 450 & 100.0 & 550 & $\begin{array}{c}100 \\
.0\end{array}$ & 556 & 100.0 & 541 & $\begin{array}{c}100 . \\
0\end{array}$ & 545 & $\begin{array}{c}100 \\
0\end{array}$ \\
\hline including: & & & & & & & & & & \\
\hline $\begin{array}{l}\text { agricultural } \\
\text { organizations }\end{array}$ & 348 & 77.3 & 452 & $\begin{array}{c}82 . \\
2\end{array}$ & 460 & 82.7 & 449 & 83.0 & 454 & 83.3 \\
\hline $\begin{array}{l}\text { population } \\
\text { managements }\end{array}$ & 96.8 & 21.5 & 88.4 & $\begin{array}{c}16 . \\
1\end{array}$ & 85.9 & 15.4 & 83.1 & 15.4 & 81.1 & 14.9 \\
\hline $\begin{array}{l}\text { peasant } \\
\text { (farming) } \\
\text { holdings) }\end{array}$ & 4.8 & 1.1 & 10.3 & 1.9 & 9.8 & 1.8 & 9.1 & 1.7 & 9.9 & 1.8 \\
\hline
\end{tabular}

Table 3 analyzes the balance of resources and use of eggs and egg products between 2000 and 2018.

Table 3. Resources and use of eggs and egg products, in million pcs.

\begin{tabular}{|c|c|c|c|c|c|c|}
\hline Indicator & 2000 & 2010 & 2014 & 2015 & 2016 & 2018 \\
\hline \multicolumn{7}{|c|}{ 1. Resources } \\
\hline Stocks at the beginning of the year & 703 & 1082 & 1146 & 1054 & 1146 & 1204 \\
\hline Production & 34085 & 40600 & 41859 & 42570 & 43559 & 44736 \\
\hline Import & 1168 & 901 & 1235 & 1236 & 1238 & 213 \\
\hline Total resources & 35956 & 42583 & 44240 & 44860 & 45943 & 46153 \\
\hline \multicolumn{7}{|c|}{ 2. Usage } \\
\hline Production consumption & 1634 & 2829 & 3528 & 3837 & 4027 & 4114 \\
\hline Losses & 34 & 102 & 72 & 86 & 77 & 80 \\
\hline Export & 326 & 244 & 305 & 354 & 452 & 489 \\
\hline Personal consumption & 33291 & 38384 & 39281 & 39437 & 40070 & 40049 \\
\hline Year-end stocks & 671 & 1024 & 1054 & 1146 & 1317 & 1421 \\
\hline \multicolumn{7}{|c|}{ 3. Dynamics of resource production, $\%$ to previous indicator } \\
\hline Stocks at the beginning of the year & & 153.9 & 105.9 & 92.0 & 108.7 & 105.1 \\
\hline Production & & 119.1 & 103.1 & 101.7 & 102.3 & 102.7 \\
\hline Import & & 77.1 & 137.1 & 100.1 & 100.2 & 17.2 \\
\hline Total resources & & 118.4 & 103.9 & 101.4 & 102.4 & 100.5 \\
\hline \multicolumn{7}{|c|}{ usage $\%$ to previous indicator } \\
\hline Production consumption & & 173.1 & 124.7 & 108.8 & 105.0 & 102.2 \\
\hline
\end{tabular}




\begin{tabular}{|l|c|c|c|c|c|c|}
\hline Losses & & 300.0 & 70.6 & 119.4 & 89.5 & 103.9 \\
\hline Export & & 74.8 & 125.0 & 116.1 & 127.7 & 108.2 \\
\hline Personal consumption & & 115.3 & 102.3 & 100.4 & 101.6 & 99.9 \\
\hline
\end{tabular}

It can be seen that the import component, which was still low, gradually decreased even more.

Table 4 shows the dynamics of prepared feed production.

Table 4. Production of prepared feed after sanctions imposed [10]

\begin{tabular}{|c|c|c|c|c|c|c|c|c|c|}
\hline \multirow[t]{2}{*}{ Indicator } & \multirow[t]{2}{*}{2014} & \multirow[t]{2}{*}{2015} & \multirow[t]{2}{*}{2016} & \multirow[t]{2}{*}{2017} & \multirow[t]{2}{*}{2018} & \multicolumn{4}{|c|}{$\begin{array}{c}\text { Dynamics, } \% \text { to previous } \\
\text { indicator }\end{array}$} \\
\hline & & & & & & 2015 & 2016 & 2017 & 2018 \\
\hline $\begin{array}{l}\text { Plant feed, } \\
\text { thousand tons }\end{array}$ & 1339 & 1246 & 1412 & 1412 & 1619 & 93.1 & 113.3 & 100.0 & 114.7 \\
\hline $\begin{array}{l}\text { Dry animal } \\
\text { feed, thousand } \\
\text { tons }\end{array}$ & 73.4 & 73.5 & 72.8 & 78.5 & 89.7 & 100.1 & 99.0 & 107.8 & 114.3 \\
\hline $\begin{array}{l}\text { Feed from fish, } \\
\text { whale meat and } \\
\text { other aquatic } \\
\text { mammals, } \\
\text { thousand tons }\end{array}$ & 2.2 & 1.3 & 4.4 & 5.6 & 3.4 & 59.1 & 338.5 & 127.3 & 60.7 \\
\hline $\begin{array}{l}\text { Feed protein, } \\
\text { thousand tons }\end{array}$ & 114 & 125 & 147 & 147 & 164 & 109.6 & 117.6 & 100.0 & 111.6 \\
\hline $\begin{array}{l}\text { Fodder } \\
\text { antibiotics, } \mathrm{t}\end{array}$ & 43.8 & 91.4 & 111 & 25.1 & 26.5 & 208.7 & 121.4 & 22.6 & 105.6 \\
\hline $\begin{array}{l}\text { Premixes, } \\
\text { thousand tons }\end{array}$ & 225 & 277 & 305 & 438 & 462 & 123.1 & 110.1 & 143.6 & 105.5 \\
\hline - for birds & 133 & - & 171 & 213 & 215 & - & - & 124.6 & 100.9 \\
\hline $\begin{array}{l}\text { Complete feed, } \\
\text { thousand tons }\end{array}$ & 23005 & 24630 & 26088 & 28051 & 29242 & 107.1 & 105.9 & 107.5 & 104.2 \\
\hline - for birds & 13028 & - & 14428 & 15484 & 15637 & - & - & 107.3 & 101.0 \\
\hline $\begin{array}{l}\text { Protein-vitamin } \\
\text { supplements, } \\
\text { thousand tons }\end{array}$ & 152 & 213 & 172 & 162 & 160 & 140.1 & 80.8 & 94.2 & 98.8 \\
\hline
\end{tabular}

After the introduction of sanctions against Russia, enterprises began to focus on their own feed base, but some components of feed continued to arrive from abroad. To reduce the cost of feed, extreme options are offered to replace natural feed with surrogate, to reduce the share of grain in feed. However, the quality of meat and eggs in poultry transferred to such feed is deteriorating. This reduces the possibility of entering foreign markets where the requirements for products quality are higher.

\section{Results}

Rapid development of the poultry industry, significant growth in the number of poultry can also have negative consequences in the future if under conditions of overproduction. It is about the overproduction of products and the difficulties of selling it. Therefore, the competitiveness growth of the industry is expected due to the development of new markets, the use of innovative developments in the field of deep processing of poultry and eggs, the formation of new marketing niches (environmental production), the development of new digital technologies. At the same time it is necessary to develop a fully domestic feed base of poultry products subcomplex.

It is proposed not only to develop integration and cooperative processes in the production, but also to use marketing tools in the research of sales markets, in particular consumers segmentation. The absolute majority of poultry producers currently focus on the 
domestic consumer with a low level of income. To ensure the marketing of products in this category, the manufacturer is focused on reducing the level of cost, often by reducing quality. However, in addition to the low segment, it is necessary to develop premium and luxury segments. Premium products are characterized by high quality of deep product processing, and luxury products should be oriented to a small segment of the population, which prefers completely eco-friendly products: poultry in this case should be reared on high quality natural feed without additives from chemical and pharmaceutical industries. Also, there should be strict selection. The sale of such products can be aimed at high-end restaurants as well as pre-order deliveries.

The sales expansion factor, such as the development of new foreign markets segments should be fully utilized. But this will require to focus on the requirements of the importing country in production.

\section{References}

1. Russian Statistical Yearbook. Collection of articles, Rosstat, 686 (Moscow, 2018)

2. Russian Statistical Yearbook. Collection of articles, Rosstat, 686 (M., 2019)

3. Agriculture, hunting and hunting entities, forestry in Russia. Collection of articles, Rosstat. 201 (Moscow, 2015)

4. G.A. Bobyleva, Poultry farming 2017: results, leaders, forecast (Tsenovik, 2018) https://www.tsenovik.ru.

5. V. Kravchenko, Meat market in Russia: results of 2019 and prospects (FSBI "Center of Agroanalytics", 2019)

6. A. Krylov, "Chickens don't peck" (Russian idiom for "rolling in money"). Farming disaster in poultry: in 2018 the production of more than a dozen large Russian poultry farms were closed and drastically reduced, Meat portal, (2019)

7. World Meat Market, International Independent Institute of Agrarian Policy, OEC, http: //image. rf/analytics/Mirovoj-rynok-masa

8. Meat market in Russia: results of 2019 and prospects, Meatinfo, https://meatinfo.ru.

9. V.I. Fisinin, Poultry farming 2020: new frontiers (Tsenovik, 2020)

10. Ministry of agriculture of Russia, http://mcx.ru.

11. Federal State Statistics Service, https://www.gks.ru. 